\title{
PERTUMBUHAN DAN HASIL PADI GOGO VARIETAS INPAGO 8 PADA BERBAGAI SISTEM TANAM DI KABUPATEN PIDIE JAYA
}

\author{
Idawanni., Fenty Ferayanti., Rini Andriani \\ Balai Pengkajian Teknologi Pertanian (BPTP) Aceh \\ J1. P. Nyak Makam No 27 Lampieneung 23125 Telp/Fax : (0651) 7551811 \\ E-mail :bptp_aceh@yahoo.co.id, Idawanniismail@yahoo.com
}

\begin{abstract}
ABSTRAK
Kajian ini bertujuan untuk mengetahui pertumbuhan dan hasil padi gogo varietas inpago 8pada berbagai system tanam yang dilaksanakan dilahan kering Desa Sarah Panyang Kecamatan pidie jaya. Pengkajian ini dilaksanakan dari bulan September- Desember 2019 dengan luas lahan 1 ha. Penelitian ini menggunakan Rancangan Acak Kelompok (RAK) dengan 3 perlakuan dan 3 ulangan. Perlakuannya adalah sistem tanam jajar legowo 2:1, jajar legowo 4:1, dan sistem tanam tegel.Setiap ulangan terdiri dari 3 plot perlakuan, pengambilan sampel dilakukan disetiap plot sebanyak 15 tanaman. Parameter tanaman yang diamati adalah pertumbuhan dan komponen hasil tanaman, yaitu : tinggi tanaman, jumlah anakan produktif, panjang malai, jumlah gabah isi per malai, persentase gabah hampa, berat 1000 butir, dan hasil gabah kering panen (GKP) per hektar. Hasil penelitian menunjukkan sistem tanam jajar legowo perpengaruh nyata pada komponen pertumbuhan dan hasil seperti, jumlah anakan produktif, panjang malai, jumlah gabah isi per malai, persentase gabah hampa dan hasil gabah ton/ ha sedangkan pada tinggi tanaman dan berat 1000 butir tidak pengaruh nyata. Sistem tanam Jajar legowo 2:1, memberikan hasil tertinggi ( 5.50 ton $\left.\mathrm{ha}^{-1}\right)$ diikuti sistem tanam legowo 4:1 (5,00 ton ha ${ }^{-1)}$, dan sistem tanam tegel ( 3.70 ton $\mathrm{ha}^{-1}$.)

Kata Kunci : Sistem tanam, pertumbuhan dan hasil, padi gogo
\end{abstract}

\section{PENDAHULUAN}

Seiring bertambahnya jumlah penduduk berdampak pada tuntutan peningkatan kebutuhan pangan khususnya beras. Proyeksi permintaan beras terus mengalami peningkatan dengan laju pertambahan penduduk $1,7 \%$ per tahun dan kebutuhan per kapita sebanyak $134 \mathrm{~kg}$ maka pada tahun 2025 Indonesia harus mampu menghasilkan padi sebayak 78 juta ton GKG untuk mencukupi kebutuhan beras nasional. Strategi untuk mencukupi dan upaya peningkatan produksi beras (padi) salah satunya dapat dilakukan dengan memperluas areal tanam pada lahan kering.

Pemanfaatan lahan kering sebagai lahan pengembangan padi gogo merupakan salah satu sumber daya yang mempunyai potensi besar untuk pemantapan swasembada pangan. Sebagaimana pendapat Abdurachman dkk., (2008) yang mengemukakan bahwa lahan kering yang potensial dapat menghasilkan bahan pangan, tidak hanya padi gogo tetapi juga bahan pangan lainnya bila dikelola dengan menggunakan teknologi yang efektif dan strategi pengembangan yang tepat. Teknologi budi daya padi gogo di lahan kering yang efektif di antaranya adalah mengatur kerapatan tanam dalam memanipulasi tanaman untuk meningkatkan hasil (Faisul-ur-Rasool dkk., 2012). Pengaturan kerapatan tanaman tersebut menggunakan sistem 
tanam jajar legowo yang dapat meningkatkan populasi tanaman per satuan luas (Erythrina dan Zaini 2014).

Sistem tanam jajar legowo merupakan rekayasa pengaturan jarak tanam antar-baris tanaman sehingga terjadi penambahan rumpun padi di dalam baris dan memperlebar jarak antarbaris tanaman.Dengan menerapkan sistem tanam jajar legowo selain produksi meningkat diharapkan juga terjadi peningkatan pendapatan petani.Sistem tanam jajar legowo jugamerupakan pengelolaan jarak tanam dan pengaturan cara tanam, sehingga diperoleh ruang tumbuh yang optimal bagi pertumbuhan dan perkembangan tanaman, menciptakan lingkungan yang sub optimal bagi organisme penganggu tanaman (OPT) serta memudahkan dalam melakukan perawatan tanaman. Tujuan tanam jajar legowo dikembangkan untuk memanfaatkan pengaruh barisan pinggir tanaman padi yang lebih banyak (Departemen Pertanian, 2005). Tanaman pinggir tumbuh dan berkembang lebih baik dan hasil per rumpun lebih tinggi dibandingkan dengan tanaman yang di tengah, sehingga semakin banyak tanaman pinggir di petakan sawah menghasilkan gabah lebih banyak.

Menurut Pahrudin dkk., (2004), padi yang ditanam secara beraturan dalam bentuk tegel, hasil tanaman per rumpun pada bagian luar lebih tinggi 1.5 hingga 2 kali dibanding hasil per rumpun tanaman yang berada di bagian dalam. Sistem tanam jajar legowo mengurangi kemungkinan serangan hama, menekan serangan penyakit, menambah populasi tanaman, meningkatakan produktivitas padi 12-22\% (Bobihoe, 2013). Sistim tanam jajar legowo juga merupakan rekayasa genetik yang ditujukan untuk memperbaiki hasil usahatani padi yang merupakan perubahan dari jarak tanam sistem tegel (biasa) menjadi tanam jajar legowo (Lalla, dkk., 2012).

Tanam jajar legowo memberikan beberapa keuntungan diantaranya memberi kemudahan dalam dalam mengendalikan gulma, penggunaan pupuk lebih berdaya guna serta pengaturan air lebih efisien. Tujuan penelitian ini adalah untuk mengetahui pertumbuhan dan hasil padi gogo varietas Inpago 8 pada berbagai sistem tanam di Kabupaten Pidie Jaya

\section{METODELOGI PENELITIAN}

Penelitian dilaksanakan pada lahan kering di Desa Sarah Panyang, Kecamatan Bandar Baru, Kabupaten Pidie Jaya. Kegiatan ini dilaksanakan mulai bulan September sampai Desember 2019 pada lahan petani dengan luas 1 ha. Bahan dan alat yang digunakan pada penelitian ini adalah benih padi varietas Inpago 8, Handtractor dan cangkul untuk mengolah tanah, gasrok untuk penyiangan gulma, meteran untuk mengukur tinggi tanaman, sabit, karung goni dan timbangan

Penelitian disusun menggunakan Rancangan Acak Kelompok (RAK) dengan tiga ulangan. Perlakuan yang di uji yaitu 3 (tiga ) macam sistem tanam yaitu : (1) jajar legowo 2:1, (2) Jajar legowo 4:1, dan (3) sistem tanam tegel. Bibit yang ditanam tiap lubang tanam berjumlah 4-5 bibit per tanam dengan cara tugal. Sistem tanam jajar legowo merupakan sistem tanam berselang dengan satu baris dikosongkan. Tanaman yang seharusnya ditanam pada barisan kosong dipindahkan sebagai tanaman sisipan didalam barisan. Cara menanam dengan menggunakan sistem legowo 2:1, yaitu setiap dua baris diselingi satu barisan kosong dengan lebar dua kali jarak dalam barisan. Namun, jarak tanam dalam barisan yang memanjang dipersempit menjadi setengah jarak tanam dalam barisan, yaitu $25 \mathrm{~cm}$ (jarak antarbarisan) x 12,5 $\mathrm{cm}$ (jarak dalam barisan) x $50 \mathrm{~cm}$ (jarak lorong). Cara menanam dengan menggunakan sistem legowo 4:1, yaitu setiap empat baris diselingi satu barisan kosong dengan lebar dua kali jarak dalam barisan. Namun, jarak tanam dalam barisan yang memanjang dipersempit menjadi 
setengah jarak tanam dalam barisan dengan jarak tanam yang sama dengan legowo $2: 1$,sedangkan cara tanam tegel yaitu tidak ada barisan yang dikosongkan dengan jarak tanam 25 $\mathrm{cm} \times 25 \mathrm{~cm}$.

Pupuk yang diberikan sebanyak $200 \mathrm{~kg} / \mathrm{ha}$ urea,100 kg/ha SP-36, dan $100 \mathrm{~kg} / \mathrm{ha}$ KCl.Urea diberikan 3 kali yaitu pada saat tanam, umur 25 HST dan umur 40 HST sedangkan SP36 dan KCL di berikan 2 kali, masing-masing 1/2 dosis pada saat tanam, dan pada umur 25 hari setelah tanam. Pupuk diberikan dengan cara di disebar diantara barisan tanaman. Pengendalianhama dan penyakit tergantung serangan (sesuai dengan kaidah PHT).

Parameter yang diamati meliputi tinggi tanaman, jumlah anakan produktif, panjang malai, jumlah gabah per malai, persentase gabah hampa, berat 1000 biji, dan hasil gabah per hektar, pengambilan sampel dilakukan disetiap plot sistem tanam sebanyak 15 tanaman. Data di Analisis of variance (Anova) dan untuk melihat perbedaan antar perlakuan dilakukan uji lanjut menggunakan Duncan Multiple Range Test (DMRT) pada taraf 5 \% (Gomez dan Gomez, 1995)

\section{HASIL DAN PEMBAHASAN}

\section{Pertumbuhan Tanaman}

Hasil analisis ragam menunjukan bahwa komponen pertumbuhan yaitu tinggi tanaman dan jumlah anakan produktif menunjukkan bahwa system tanam tidak berpengaruh nyata terhadap tinggi tanaman akan tetapi berpengaruh nyata terhadap pertumbuhan jumlah anakam produktif, hal ini dapat dilihat pada Tabel 1.

Tabel 1. Tinggi tanaman dan Jumlah anakan produktif padaberbagai sistem tanam

\begin{tabular}{clcc}
\hline No & Sistem tanan & $\begin{array}{c}\text { Tinggi Tanaman } \\
(\mathrm{cm})\end{array}$ & $\begin{array}{c}\text { Anakan Produktif } \\
\text { (btg/rumpun) }\end{array}$ \\
\hline 1. & Legowo 2:1 & $109,94^{\mathrm{a}}$ & $15^{\mathrm{b}}$ \\
2. & Legowo 4:1 & $110,64^{\mathrm{a}}$ & $14^{\mathrm{b}}$ \\
3. & Tegel & $112,05^{\mathrm{a}}$ & $10^{\mathrm{a}}$ \\
\hline
\end{tabular}

Keterangan: Angka-angka yang diikuti oleh huruf yang sama menunjukkan tidak berbeda nyata (uji Duncan ${ }_{0,05}$ ).

Tabel 1 menunjukkan bahwa tinggi tanaman pada sistem tanam jajar legowo 2 : 1 tidak berbeda nyata dengan sistem tanam legowo 4 : 1 dan system tanam tegel, akan tetapi angka teringgi di jumpai pada sistem tanam tegel hal ini sesuai pendapat Nursanti (2009) yang menyatakan bahwa pertambahan tinggi tanaman ini disebabkan karena tajuk tanaman yang semakin merapat mengakibatkan kualitas cahaya yang diterima menjadi menurun. Semakin rapat jarak tanam yang dipakai maka pertumbuhan tinggi tanaman akan semakin cepat karena tanaman saling berusaha mencari sinar matahari yang lebih banyak. Hasil penelitian yang sama juga dikemukakan oleh Aribawa dan Kariada (2005) yang menyatakan tinggi tanaman akan lebih tinggi dihasilkan pada populasi tanaman yang lebih padat dalam satu hamparan.

Adapun pada jumlah anakan produktif angka tertinggi di jumpai pada perlakuan jajar legowo 2:1, yang tidak berbeda nyata dengan jajar legowo 4:1dan berbeda nyata dengan sistem tanam tegel. Varietas Inpago 8 cenderung memberikan anakan produktif lebih banyak bila ditanam pada populasi yang lebih sedikit. Hal ini membuktikan bahwa respon tanaman terutama anakan produktif pada jarak tanam yang lebar pada sistem jajar legowo mengakibatkan tanaman dapat tumbuh lebih leluasa sehingga ketersediaan unsur hara dapat diserap lebih optimal oleh tanaman. Sistem tanam jajar legowo memberikan ruang yang berbeda dalam memperoleh cahaya 
matahari yang dipergunakan tanaman dalam proses fotosintesis. Semakin banyak cahaya matahari yang bisa diserap tanaman semakin cepat proses fotosintesis berlangsung dan pada akhirnya mempercepat pertumbuhan tanaman.

Husana (2010), menyatakan bahwa jumlah anakan akan maksimal apabila tanaman memiliki sifat genetik yang baik di tambah dengan keadaan lingkungan yang menguntungkan atau sesuai dengan pertumbuhan dan perkembangan tanaman. Selanjutnya dikemukakan bahwa jumlah anakan maksimum juga ditentukan oleh jarak tanam, sebab jarak tanam menentukan radiasi matahari, hara mineral serta budidaya tanaman itu sendiri. Selain itu faktor lain yang bisa juga mempengaruhi tinggi tanaman yaitu kondisi lahan, cuaca dan iklim ditempat penelitian, gen dari varietas itu sendiri.

\section{Komponen Hasil}

Komponen hasil tanaman yang diamati adalah panjang malai, jumlah gabah per malai, persentase gabah hampa, dan berat 1.000 butir. Hasil penelitian menunjukkan bahwa perlakuan sistem tanam berbeda nyata terhadap panjang malai, dan jumlah gabah per malai, persentase gabah hampa. Sedangkan berat 1.000 butir tidak menunjukkan pengaruh secara nyata (Tabel 2).

Tabel 2. Panjang malai, Jumlah gabah isi per malai, Persentase gabah hampa per malai, dan Berat 1000 biji pada berbagai sistem tanam

\begin{tabular}{llcccc}
\hline No & Sistem tanam & $\begin{array}{c}\text { Panjang } \\
\text { malai }(\mathrm{cm})\end{array}$ & $\begin{array}{c}\text { Jumlah } \\
\text { gabah isi per } \\
\text { malai (btr) }\end{array}$ & $\begin{array}{c}\text { Persentase } \\
\text { hampa(\%) }\end{array}$ & $\begin{array}{c}\text { Berat } \\
1000 \text { biji }(\mathrm{g})\end{array}$ \\
\hline 1. & Legowo 2:1 & $24,40^{\mathrm{ab}}$ & $117,55^{\mathrm{b}}$ & $8,50^{\mathrm{a}}$ & 26,60 \\
2. & Legowo 4 : 1 & $23,10^{\mathrm{ab}}$ & $114,53^{\mathrm{b}}$ & $11,32^{\mathrm{b}}$ & 25,40 \\
3. & Tegel & $21,20^{\mathrm{a}}$ & $111,10^{\mathrm{a}}$ & $12,60^{\mathrm{b}}$ & 25,25 \\
\hline
\end{tabular}

Keterangan: Angka-angka yang diikuti oleh huruf yang sama menunjukkan tidak berbeda nyata ( uji Duncan ${ }_{0,05}$ ).

Pada Tabel 2 terlihat bahwa panjang malai berkisar 22,20-24,40 cm, dimana malai terpanjang didapat pada perlakuan jajar legowo 2:1 $(24,40 \mathrm{~cm})$ yang tidak berbeda nyata dengan sistem tanam legowo 4:1 dan berbeda nyata dengan sistem tanam tegel. Jumlah gabah per malai berkisar 111,10-117,55 butir, dimana jumlah yang terbanyak didapat pada perlakuan jajar legowo 2:1 (117,55 butir) dan tidak berbeda nyata dengan perlakuan legowo 4:1. Jumlah gabah yang terendah dijumpai pada perlakuan sistem tanam tegel $(111,10)$ yang berbeda sangat nyata dengan sistem tanam jajar legowo lainnya. Sedangkan persentase gabah hampa tertinggi dijumpai pada perlakuan sistem tanam tegel yang berbeda nyata dengan sistem tanam legowo 2:1 dan tidak berbeda nyata dengan sistem tanam legowo 4:1

Hal ini sesuai pendapat Aribawa (2012), penerapan jajar legowo dapat mempengaruhi panjang malai yang berkorelasi terhadap jumlah gabah per malai, semakin panjang malainya maka semakin banyak peluang gabah yang dapat ditampung oleh malai. Khairullah dkk., (2001) melaporkan adanya kecenderungan peningkatan hasil gabah pada malai yang lebih panjang. Sementara itu, jumlah gabah bernas dan bobot biji yang terbentuk dalam satu malai sangat bergantung dari proses fotosintesis dari tanaman selama pertumbuhannya dan sifat genetis dari tanaman padi yang dibudidayakan. Semakin banyak energy cahaya matahari yang dikonversi dalam proses fotosintesis akan berpengaruh pada pertumbuhan tanaman yang lebih baik sehingga mampu menghasilkan anakan dengan jumlah gabah lebih banyak (Anggraini, 2013). 
Ada kecendrungan juga bahwa semakin banyak populasi tanaman maka jumlah gabah juga semakin meningkat. Hal ini disebabkan makin banyak lorong yang terdapat pada sistem tanam jajar legowo mengakibatkan intensitas cahaya matahari yang sampai ke permukaan daun lebih banyak terutama pada pinggir lorong sehingga meningkatkan efisiensi fotosintesa (Abdullah dkk., 2000). Selanjutnya menurut Fagi (1989), sistem tanam jajar legowo 2 : 1 mampu mengoptimalkan pembentukan dan pengisian gabah melalui intensitas sinar matahari yang diterima. Walaupun memiliki jumlah anakan produktif tinggi tetapi tidak diikuti dengan persentase gabah isi yang tinggi maka hasil yang dicapai akan rendah (Hanarida 1990). Jumlah gabah per malai berkorelasi positif dengan jumlah gabah isi dan produksi artinya semakin tinggi jumlah gabah permalai maka semakin tinggi peluang varietas tersebut dapat menghasilkan produksi selama jumlah gabah hampa tidak tinggi (Lestari 2007).

\section{Hasil Gabah}

Hasil analisis statistik pada Tabel 3 terhadap hasil gabah ton/ha menunjukkan system tanam legowo 2 : 1 tidak berbeda nyata dengan system tanam $4: 1$ akan tetapi berpengaruh sangat nyata terhadap sistem tanam tegel, Pada perlakuan sistem tanam legowo 2 : 1 menunjukkan hasil tertinggi (5,50 ton/ ha), diikuti sistem tanam $4: 1$ (5,00 ton/ ha) dan terendah pada sistem tanam tegel $(3,70$ ton/ ha).

Tabel 3.Hasil gabah per hektar varietas padi Inpogo 8 pada berbagai sistem tanam

\begin{tabular}{llc}
\hline No & \multicolumn{1}{c}{ Sistem tanan } & Hasil gabah ton/ha \\
\hline 1. & Legowo 2:1 & $5,50^{\mathrm{b}}$ \\
2. & Legowo 4:1 & $5,00^{\mathrm{b}}$ \\
4. & Tegel & $3,70^{\mathrm{a}}$ \\
\hline
\end{tabular}

Keterangan: Angka-angka yang diikuti oleh huruf yang sama menunjukkan tidak berbeda nyata (uji Duncan $_{0,05}$ ).

Hal ini sesuai dengan hasil penelitian Marthen (2011) bahwa sistem jajar legowo 2:1 dapat meningkatkan produktivitas lebih tinggi dibandingkan jajar legowo 4:1.Menurut hasil penelitian Tryani dkk., (2004), sistem tanam jajar legowo 2:1 akan menjadikan semua barisan rumpun tanaman berada pada bagian pinggir, dengan kata lain seolah olah semuarumpun tanaman berada di pinggir gelengan, sehingga semua tanaman mendapat efek samping dan tanaman yang mendapat efek samping produksinya lebih tinggi dari pada yang tidak mendapatkannya. Tanaman yang mendapat efek samping, menjadikan tanaman tersebut mendapatkan faktor-faktor tumbuhan yang tersedia seperti cahaya matahari, air dan $\mathrm{CO}^{2}$ dengan lebih baik untuk pertumbuhan dan pembentukan hasil, karena kompetisi yang terjadi relatif kecil.

Hal ini sesuai dengan pendapat Sumardi (2010) yang menyatakan bahwa semakin rendah populasi tanaman maka hasil gabah per rumpun akan cenderung meningkat. Adanya lorong kosong pada sistem legowo mempermudah pemeliharaan tanaman, seperti pengendalian gulma dan pemupukan yang dapat dilakukan dengan lebih mudah. Menurut Salahuddin dkk., (2009), jarak tanam mempengaruhi panjang malai, jumlah bulir per malai, dan hasil per hektar tanaman padi 


\section{KESIMPULAN}

Sistem tanam jajar legowo perpengaruh nyata pada komponen pertumbuhan dan hasil seperti, jumlah anakan produktif, panjang malai, jumlah gabah isi per malai, persentase gabah hampa dan hasil gabah ton/ha sedangkan pada tinggi tanaman dan berat 1.000 butir tidak pengaruh nyata. Sistem tanam Jajar legowo 2:1, memberikan hasil tertinggi (5,50 ton/ ha) diikuti sistem tanam legowo 4:1 (5,00 ton/ ha), dan sistem tanam tegel $(3,70$ ton/ ha)

\section{DAFTAR PUSTAKA}

Abdurachman, A., Dariah, A., Mulyani, A. 2008. Strategi dan Teknologi Pengelolaan Lahan Kering Mendukung Pengadaan Pangan Nasional. Jurnal Litbang Pertanian. 27(2): 4349.

Anggraini, F., Suryanto, A., Aini, N. 2013. Sistem Tanam dan Umur Bibit pada Tanaman Padi Sawah (Oryza sativa L.) Varietas Inpari 13. Jurnal Produksi Tanaman 5 (1): 52-60.

Aribawa, I.B. 2012. Pengaruh sistem tanam terhadap peningkatan produktivitas padi si lahan sawah dataran tinggi beriklim basah. Balai Pengkajian Teknologi Pertanian (BPTP) Bali. Denpasar.

Aribawa, IB., Kariada. 2005. Pengaruh Sistem Tanam terhadap Pertumbuhan dan Hasil Beberapa Varietas Padi Sawah di Subak Babakan Tabanan. Proseding Seminar Nasional Optimalisasi Teknologi Kreatif dan Peran Stakeholder Dalam Percepatan Adopsi Inovasi Teknologi Pertanian Pusat Sosial Ekonomi dan Kebijakan Pertanian Berkerjasama dengan BPTP Bali. 159-163

Bobihoe. 2011. Keuntungan Tanam Padi Jajar Legowo. Balai Pengkajian Teknologi Pertanian Jambi. Jambi.

Departemen Pertanian. 2005. Budidaya Mina Padi Azolla dengan Tanam Jajar Legowo. Departemen Pertanian. Jakarta.

Erythrina., Zaini, Z. 2014. Budi Daya Padi Sawah Sistem Tanam Jajar Legowo: Tinjauan Metodologi untuk Mendapatkan Hasil Optimal. Jurnal Litbang Pertanian. 33(2): 79-86

Fagi, A.M., De Datta, S.K. 1989. Environmental Factors Affecting Nitrogen Efficiency in Flooded Tropical Rice. Journal of Fertilizer Research. 2:52-67

Faisul-ur-Rasool., Habib., R. Bhat., MI. 2012. Evaluation of Plant Spacing and Seedlings per Hill on Rice (Oryza sativa l.) Productivity Under Temperate Conditions. Pakistan Journal Agriculture Sciences. 49: 169-172.

Gomez, A.K., Gomez., A.A. 2007. Prosedur Statistik untuk Penelitian. Jakarta : Universitas Indonesia Press.

Hanarida, I.S., Sahi, I., Diredja, M. 1990. Penampilan Galur Harapan Padi Gogo. Dalam: Nurbaeti N., Permadi, K., Sukanata, I.K. Pengujian Varietas Padi Hibrida di Lahan Sawah Intensif Kabupaten Sumedang. Jurnal Agrijati. 15 (1): 82-87

Husana, Y. 2010. Pengaruh Penggunaan Jarak Tanam terhadap Pertumbuhan dan Produksi Padi Sawah (Oryza sativa L.) Varietas IR 42 dengan Metode SRI (System of Rice Intensification). Jurnal Jurusan Agroteknologi. Fakultas Pertanian. Universitas Riau. 9 : 2-7.

Khairullah, I., Subowo, S., Sulaiman, S. 2001. Daya Hasil dan Penampilan Fenotipik GalurGalur Harapan Padi Lahan Pasang Surut di Kalimantan Selatan. Prosiding Kongres IV 
dan Simposium Nasional Perhipi. Peran Pemuliaan dalam Memakmurkan Bangsa. Perhipi Komda DIY dan Fakultas Pertanian Universitas Gajah Mada. 169-174

Lalla, H.S., Saadah, A. 2012. Adopsi Petani Padi Sawah terhadap Sistem Tanam Jajar Legowo 2:1 di Kecamatan Polong Bangkaeng Utara, Kabupaten Takalar. Jurnal Sains dan Teknologi. 3(12):255-264.

Lestari, A.P., Nugraha. Y. 2007. Keragaan Genetik Hasil dan Kompone Hasil Galur-Galur Padi Hasil Kulturanter. Jurnal Penelitian Pertanian Tanaman Pangan. 25(1): 8-13.

Marthen, P. S. 2011. Kajian Perbaikan Teknologi Budidaya Padi Melalui Penggunaan Varietas Unggul dan Sistem Tanam Jajar Legowo dalam Meningkatkan Produktivitas Padi Mendukung Swasebada Pangan. Jurnal Budidaya Pertanian 7 (2):79-87

Nursanti, R. 2009. Pengaruh Umur Bibit dan Jarak Tanam terhadap Pertumbuhan dan Produktivitas Tanaman Buru Hotong (Setaria italica (L.) Beauv). Skripsi. Program Studi Agronomi. Fakultas Pertanian. Institut Pertanian Bogor.

Pahrudin, A., Maripul., Dida, P.R. 2004. Cara Tanam Padi Sistem Legowo Mendukung Usaha Tani di Desa Bojong Cikembar Sukabumi. Buletin Tehnik Pertanian IX (1) : 10-12.

Salahuddin, K.M., Chowhdury, S.H,. Munira, S., Islam, M.M., Parvin, S. 2009. Response of Nitrogen and Plant Spacing of Transplanted Aman Rice. Bangladesh Journal Agriculture Research. 34(2): 279-285.

Sumardi. 2010. Produktivitas Padi Sawah pada Kepadatan Berbeda. Jurnal Ilmu-ilmu Pertanian Indonesia XII (1) : 49-54.

Triany, S., Kadir, E., Suhartatik., Sutisna, E. 2004. Petunjuk Teknis Budidaya PTB cara PTT. Makalah disampaikan pada Pelatihan Pengembangan Varietas Unggul Tipe Baru (VUTB) Fatmawati dan Vub Lainnya, 31 Maret-3 April 2004 di Balitppa, Sukamandi. wordpress. com/2012/01/17/ kajian perbaikan teknologi budidaya padi melalui penggunaan varietas unggul dan sistem tanam jajar legowo dalam meningkatkan produktivitas padi mendukung swasembada pangan/. Diakses tanggal 4 Juni 2018. 